TECTONICS, VOL. 12, NO. 1, PAGES 291-300, FEBRUARY 1993

\section{SLOW APPARENT POLAR WANDER FOR NORTH AMERICA IN THE LATE TRIASSIC AND LARGE COLORADO PLATEAU ROTATION}

\author{
Dennis V. Kent and William K. Witte \\ Lamont-Doherty Geological Observatory of Columbia \\ University, Palisades, New York
}

Abstract. Several recent analyses of North American paleomagnetic data suggest fast apparent polar wander (APW) $(\sim 0.75 \%$ m.y.) during the Late Triassic and a modest amount $\left(-5^{\circ}\right)$ of Colorado Plateau clockwise rotation. Paleomagnetic poles from the lower (Carnian), middle (Norian), and upper (Hettangian) stratigraphic intervals of the Newark Basin, however, indicate very slow APW over the Late Triassic and provide an alternative interpretation for plateau rotation. The middle Newark pole is supported by positive fold and reversal tests, precluding remagnetization, and agrees well with the pole reported from the Norian Upper Shale Member of the Chinle Formation from east central New Mexico as well as the $214 \mathrm{Ma}$ Manicouagan pole from Quebec. These poles provide a welldefined mean Norian reference pole for cratonic North America at $57.4^{\circ} \mathrm{N} 91.0^{\circ} \mathrm{E}$ A95 $=3.8^{\circ}$. Paleomagnetic poles from the Chinle Formation on the Colorado Platean (Owl Rock Member, Church Rock Member, and our new result from the upper Chinle in Utah) are also well grouped, consistent with slow APW over the Norian, but give a mean pole position $\left(57.7^{\circ} \mathrm{N} 65.6^{\circ} \mathrm{E} \mathrm{A} 95=2.5^{\circ}\right)$ that differs significantly from the Norian pole for cratonic North America. The North American Norian poles can be closely reconciled by a $13.5^{\circ} \pm 3.5^{\circ}$ correction for accumulated post-Triassic clockwise rotation of the Colorado Plateau associated with Laramide deformation and Cenozoic opening of the Rio Grande Rift. This estimate of Colorado Plateau rotation is consistent with a systematic discrepancy between plateau and cratonic poles for the Early Triassic, whereas available late Paleozoic and Jurassic poles are judged not to provide definitive constraints on plateau rotation. A revised Triassic and Early Jurassic APW path for North America shows that the virtual standstill in the Norian, the last 15 m.y. of the Triassic, was preceded and followed by intervals of fast $(\sim 1 \%$ m.y.) angular plate velocity.

\section{INTRODUCTION}

To explain Cretaceous Laramide deformation in the Rocky Mountain region and Cenozoic extension in the Rio Grande Rift, Hamilton [1981] proposed that the Colorado Plateau rotated clockwise in two phases relative to the stable craton of North America. Because many late Paleozoic and Mesozoic paleomagnetic reference poles for North America come from the Colorado Plateau, detailed descriptions of the apparent polar wander (APW) path for cratonic North America and paleomagnetic estimates of the amount of Plateau rotation tend to be strongly interdependent. A central issue is whether net clockwise rotation of the Colorado Plateau was small $\left(\leq 5^{\circ}\right)$ or large $\left(\geq 10^{\circ}\right)$.

The paleomagnetic Euler pole (PEP) model of APW for North America [Gordon et al., 1984; May and Butler, 1986]

Copyright 1993 by the American Geophysical Union.

Paper number $92 \mathrm{TC} 01966$.

0278-7407/93/92TC-01966\$10.00 predicts an angular plate velocity at a constant rate of about $0.75 \% \mathrm{~m}$.y. in the Triassic, and a similarly fast rate $(0.66 \% \mathrm{~m} . \mathrm{y}$.) in almost the opposite direction over much of the Jurassic. This model of APW is a critical assumption in the determination of rotation of the Colorado Plateau by the method of Bryan and Gordon [1986, 1990]. They most recently estimated a clockwise plateau rotation of $5.0^{\circ} \pm 2.5^{\circ}$ to optimize the fit of late Paleozoic to Jurassic paleomagnetic poles from the plateau and cratonic North America to a PEP model path. Even though Steiner [1986, 1988] has maintained that some pole-to-pole differences indicate a larger plateau rotation of $11^{\circ} \pm 4^{\circ}$, Bryan and Gordon [1990] rejected at a high formal level of confidence $(99.99 \%)$ the hypothesis that a systematic difference could be as large as $10^{\circ}$.

Bryan and Gordon [1990] acknowledged that Cretaceous poles, which are not available from the Colorado Plateau, do not contribute directly to the estimate of plateau rotation and should therefore be excluded from analysis. We suggest that Jurassic and Permian poles also do not provide cogent constraints on the amount of plateau rotation in the light of new data. The synthesis by May and Butler [1986] already showed that there are virtually no coeval cratonic and plateau counterparts in the inventory of North American Jurassic poles. Now even the overall reliability of many of the Jurassic reference poles has become the subject of debate, with the availability of new but often conflicting paleomagnetic results that allow rather divergent interpretations of Jurassic APW [Van Fossen and Kent, 1990, 1992a, b; Butler et al., 1992]. With regard to late Paleozoic paleomagnetic data, Gordon et al. [1984] recognized that Permian poles from on the plateau showed no discernible difference from those off the plateau, even though Triassic poles suggested plateau rotation of about $10^{\circ}$. To explain this discrepancy, Steiner [1988] suggested that the Colorado Plateau experienced a separate rotation in the Late Permian, prior to the Laramide and Cenozoic rotations that are of interest here. The tectonic implication of the Permian poles is complicated, however, by new evidence that portions of central New Mexico east of the Rio Grande Rift, where some key Permian poles that have been regarded as cratonic references were obtained, experienced a similar sense of rotation as the Colorado Plateau [Molina-Garza et al., 1991].

Our attention therefore focuses on the Triassic for which recent paleomagnetic studies provide what we regard as more coherent information to separate North American APW from Colorado Plateau rotation. The key pole positions in our analysis include Late Triassic poles from Newark Basin sedimentary rocks [Witte and Kent, 1989; Witte et al., 1991] and the compilation of Late Triassic North American poles judged as reliable by Bazard and Butler [1991], with supportive data from our paleomagnetic study of the Chinle Formation. Our synthesis supports the virtmal absence of APW in the Late Triassic that was independently suggested by the Newark results and shows that post-Triassic net clockwise rotation of the Colorado Plateau must have been consequently large.

\section{EVIDENCE FOR SLOW APW IN THE LATE TRIASSIC}

\section{Cratonic North American Data}

The Newark Basin is the largest $(250 \mathrm{~km}$ long and $50 \mathrm{~km}$ wide) of a chain of Mesozoic rift basins in eastem North America that developed in the early stages of formation of the Atlantic Ocean. It contains more than $6 \mathrm{~km}$ of lacustrine and fluvial sediments in a continuous sequence spanning more than 
25 m.y., from the middle Carnian to the Hettangian [Cornet and Olsen, 1985]. The paleomagnetically well-studied tholeiitic basalts and associated diabase intrusions are volumetrically important but are now believed to have been emplaced as part of a short-lived (circa 1 m.y.) igneous episode just after the Triassic/Jurassic boundary [Olsen and Fedosh, 1988; Olsen and Sues, 1986]. The most reliable age for the igneous activity is $201 \pm 1 \mathrm{Ma}$, based on U/Pb zircon dating on baddeleyite [Dunning and Hodych, 1990], which is in good agreement with an age of $200 \mathrm{Ma}$ for the Triassic/Jurassic boundary in the Triassic time scale of Webb [1981]. Younger ages that have been reported for the igneous intrusions are now ascribed to resetting by a hydrothermal event at about $175 \mathrm{Ma}$ [Sutter, 1988], which may very well have also remagnetized the igneous intrusions and overprinted the basalt magnetizations [Witte and Kent, 1989, 1990, 1991]. For these and related reasons, the status of paleomagnetic poles from the Newark trend igneous rocks (labeled N1 and N2 by May and Butler [1986], after Smith and Noltimier [1979]) is sufficiently in doubt that these once key reference poles have not been used in recent analyses of Jurassic APW [e.g., Bazard and Butler, 1991].

The paleomagnetic study of the Newark Basin by McIntosh et al. [1985] included a comprehensive sampling of the sedimentary rocks. The presence of normal and reversed polarities provided evidence for the preservation of an ancient component of magnetization in the Newark sedimentary section, but the significance of the paleomagnetic directions in terms of APW was obscured because of incomplete removal of secondary magnetizations after thermal demagnetization to only $550^{\circ} \mathrm{C}$ for most samples.

Based on complete demagnetization analysis, renewed work on the Newark sedimentary rocks has yielded three well defined paleopoles from three intervals in stratigraphic succession. A lower Newark pole was obtained from Carnian red beds of the Stockton, Lockatong and lowermost Passaic formations
(53.5N $101.6^{\circ} \mathrm{E}$ A95=4.8 ${ }^{\circ}$; Witte and Kent, 1989], a middle Newark pole from Norian red beds of the Passaic Formation $\left(55.9^{\circ} \mathrm{N} 95.0^{\circ} \mathrm{E}\right.$ A95 $=4.4^{\circ}$ [Witte et al., 1991]), and an upper Newark pole from Hettangian red beds interbedded with the Watchung basalts of the igneous extrusive zone $\left(55.3^{\circ} \mathrm{N} 94.5^{\circ} \mathrm{E}\right.$ A95 $=5.4^{\circ}$ [Witte and Kent, 1990]) (Figure 1). These paleopoles are not significantly different from one another; the largest difference $\left(4.5^{\circ} \pm 6.5^{\circ}\right)$ is between the lower Newark and middle Newark poles, whereas the middle Newark and upper Newark poles differ by less than $1^{\circ}$. The reliability of the Newark poles is supported by a regionally coherent magnetic polarity stratigraphy, which is now being corroborated in detail from the results of the Newark Basin Coring Project [Kent et al., 1991], and by a positive fold test on a syndepositional fold and a positive reversal test for the middle Newark pole [Witte et al., 1991]. This evidence clearly shows that remagnetization is not a viable explanation for the similarity in paleomagnetic poles from lower, middle, and upper Newark rocks.

The Newark Basin developed along the structural grain of Precambrian and early Paleozoic crystalline basement [Ratcliffe et al., 1986; Swanson, 1986], making unlikely appreciable vertical axis rotation of the entire basin with respect to the stable craton of North America. The possibility of "cryptic" tectonic rotations localized to the border fault zone of the Newark Basin has been suggested by Van Fossen et al. [1986], however, to explain aberrant paleomagnetic directions obtained from the western limb of the Watchung syncline. Regardless of whether the aberrant directions are in fact due to local rotation, for which there is no geological evidence, or can be explained by secular variation bias or other mechanisms [Kodama, 1987; Van Fossen et al., 1987], we have not observed such systematic discrepancies where we have sampled elsewhere in the Newark Basin. For example, the paleomagnetic directions from 15 sites taken on both limbs of the Jacksonwald syncline near the border fault give a positive fold test and are concordant with the mean

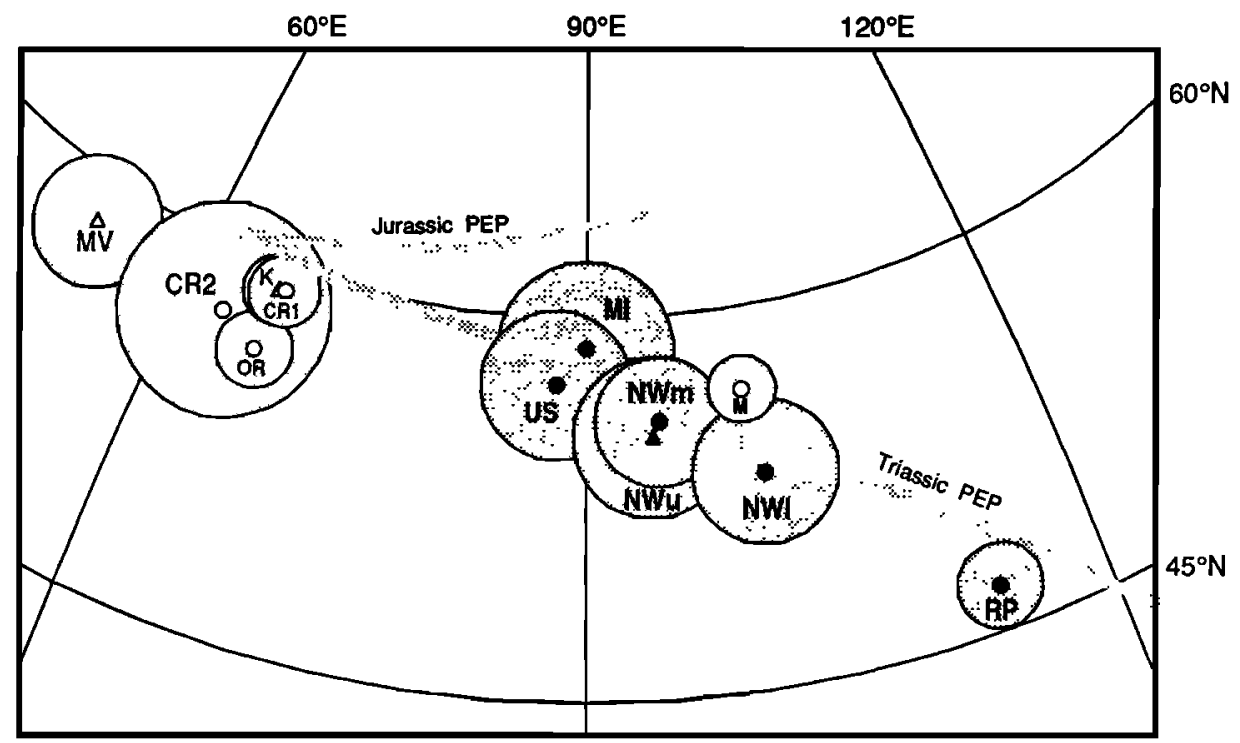

Fig. 1. Selected Triassic (circles) and Early Jurassic (triangles) paleomagnetic poles for North America with no correction for Colorado Plateau rotation. Open symbols with light confidence envelopes are poles from Colorado Plateau and solid symbols with dark confidence envelopes are poles from off the plateau (see Table 1 for abbreviations), with standard error (63\% confidence) circles approximated as $58 \%$ of A95. Shown for reference by stippled curves are the Triassic paleomagnetic Euler pole (PEP) track and the ensuing portion of the Jurassic PEP track from Gordon et al. [1984]. 
direction of eight sites from the interior of the basin where strata of similar Norian age are gently homoclinal [Witte et al., 1991]. The 23 middle Newark site mean directions were further shown to be statistically compatible with a circular (Fisherian) distribution, without an elongated scatter or streaking that might be expected from either rotations about local vertical axes or sampling of rapid APW.

Slow APW during at least the Norian stage of the Late Triassic is supported by the consistency of the middle Newark pole with other paleomagnetic results from cratonic North America regarded as reliable by Bazard and Butler [1991]. A new paleomagnetic pole with a positive reversal test from the early Norian Upper Shale Member of the Chinle Formation in east central New Mexico falls at $57.4^{\circ} \mathrm{N} 87.8^{\circ} \mathrm{E}$ A95 $=5.0^{\circ}$ [Bazard and Butler, 1991], which is within $4.2^{\circ}$ of and therefore not significantly different from the Norian middle Newark pole (Figure 1). Similarly, paleomagnetic results from the Manicouagan impact structure in the Precambrian shield of Quebec [Robertson, 1967; Larochelle and Currie, 1967] give a mean pole position at $58.8^{\circ} \mathrm{N} 89.9^{\circ} \mathrm{E}$ A95 $=5.8^{\circ}$ [Bazard and Butler, 1991] that is not significantly different from the middle Newark pole (Figure 1). New high-precision dating by the $\mathrm{U} / \mathrm{Pb}$ zircon method puts the age of the Manicouagan melt rocks at $214 \pm 1 \mathrm{Ma}$ [Hodych and Dunning, 1992], which corresponds to the Norian according to time scales as diverse as those of Webb [1981] and Harland et al. [1990].

The well-defined mean of the middle Newark, Upper Shale and Manicouagan poles (Table 1) at $57.4^{\circ} \mathrm{N} 91.0^{\circ} \mathrm{E}$ A95 $=3.8^{\circ}$ can therefore be regarded as representative of the stationary pole position with respect to cratonic North America over the
Norian, approximately the last $15 \mathrm{~m} . y$. of the Triassic (215 Ma to $200 \mathrm{Ma}$ [Webb, 1981] or $223 \mathrm{Ma}$ to $208 \mathrm{Ma}$ [Harland et al., 1990]).

\section{Colorado Plateau Data}

For the Colorado Plateau, paleomagnetic data are available from rocks of similar Norian age from the Chinle Formation. The middle Norian Owl Rock Member sampled in northeastern Arizona gives a pole position supported by a positive reversal test at $56.5^{\circ} \mathrm{N} 66.4^{\circ} \mathrm{E}$ A95 $=2.6^{\circ}$ [Bazard and Butler, 1991] (Figure 1). From paleomagnetic results obtained by Reeve [1975] from the stratigraphically overlying (mid-late Norian) Church Rock Member in southern Utah, Bazard and Butler [1991] recalculated a pole position at $59.0^{\circ} \mathrm{N} 67.0^{\circ} \mathrm{E} A 95=2.5^{\circ}$ that is virtually identical to the Owl Rock pole. Support for this early work on the Church Rock member comes from our own paleomagnetic study of approximately equivalent strata of the Chinle Formation sampled on the San Rafael swell and near Moab, Utah. On the basis of complete progressive thermal demagnetization to $680^{\circ} \mathrm{C}$, we obtain high unblocking temperature characteristic directions from nine sites that pass a reversal test and give a mean paleopole position at $57.5^{\circ} \mathrm{N}$ $63.3^{\circ} \mathrm{E}$ A95 $=7.3^{\circ}$ (see Appendix) (Figure 1).

These three Chinle poles from the Colorado Plateau are very well grouped (Table 1). In the absence of a fold test or a regional magnetostratigraphy, remagnetization of the Chinle has been suggested [Witte et al., 1991], but we find this explanation increasingly unlikely in view of the positive reversal test reported for the Owl Rock member by Bazard and

TABLE 1. Selected Triassic and Early Jurassic Paleomagnetic Poles for North America

\begin{tabular}{|c|c|c|c|c|c|c|c|c|c|}
\hline & \multirow[b]{2}{*}{ Rock Unit } & \multirow[b]{2}{*}{ Age } & \multicolumn{2}{|c|}{ Plateau } & \multicolumn{2}{|c|}{ Cratonic } & \multirow[b]{2}{*}{$\begin{array}{r}\text { A95, } \\
\text { degrees }\end{array}$} & \multirow[b]{2}{*}{ K } & \multirow[b]{2}{*}{ Ref } \\
\hline & & & $\begin{array}{l}\text { Plat, } \\
{ }^{\circ} \mathrm{N}\end{array}$ & $\begin{array}{l}\text { Plon, } \\
{ }^{\circ} \mathbf{E}\end{array}$ & $\begin{array}{l}\text { Plat, } \\
{ }^{\circ} \mathrm{N}\end{array}$ & $\begin{array}{c}\text { Plon, } \\
{ }^{\circ} \mathrm{E}\end{array}$ & & & \\
\hline $\mathbf{K}$ & Kayenta & Pliensbachian & 59.0 & 66.6 & $(58.1$ & 92.5) & 2.4 & 155 & 1 \\
\hline MV & Moenave & Sinemurian & 58.2 & 51.9 & $(60.1$ & $78.0)$ & 4.5 & 45 & 2 \\
\hline NWu & Newark upper & Hettangian & & & 55.3 & 94.5 & 5.4 & 72 & 3 \\
\hline NWm & Newark middle & Norian & & & 55.9 & 95.0 & 4.4 & 49 & 4 \\
\hline US & Upper Shale & Norian & & & 57.4 & 87.8 & 5.0 & 60 & 1 \\
\hline MI & Manicouagan & $214 \pm 1 \mathrm{Ma}$ & & & 58.8 & 89.9 & 5.8 & & $5,6,1$ \\
\hline \multicolumn{3}{|c|}{ Mean Cratonic Norian (MI, US, NWm): } & & & 57.4 & 91.0 & 3.8 & 1063 & \\
\hline CR2 & Church Rock & Norian & 57.5 & 63.3 & $(57.3$ & 88.4) & 7.3 & 50 & 7 \\
\hline CR1 & Church Rock & Norian & 59.0 & 67.0 & $(58.0$ & 92.8) & 2.5 & 72 & 8,1 \\
\hline OR & Owl Rock & Norian & 56.5 & 66.4 & $(55.8$ & 90.7) & 2.6 & 145 & 1 \\
\hline \multicolumn{3}{|c|}{ Mean Plateau Norian (OR, CR1, CR2): } & 57.7 & 65.6 & $(57.1$ & 90.7) & 2.5 & 2426 & \\
\hline NW1 & Newark lower & Carnian & & & 53.5 & 101.6 & 4.8 & 50 & 9 \\
\hline M & Moenkopi & Scythian & 56.8 & 100.9 & $(50.4$ & 120.9) & 2.3 & 1630 & 10 \\
\hline $\mathbf{R P}$ & Red Peak & Scythian & & & 46.8 & 113.7 & 2.9 & 1835 & 10 \\
\hline
\end{tabular}

Plat and Plon are the latitude and longitude of the paleomagnetic pole in Colorado Plateau and/or cratonic North America coordinates, with pole positions in parentheses correcled for $13.5^{\circ}$ of clockwise plateau rotation about an Euler pole at $36^{\circ} \mathrm{N} 105^{\circ} \mathrm{W}$. A95 is radius of cone of $95 \%$ confidence about pole; $K$ is estimate of Fisher precision parameter. References (Ref) are 1, Bazard and Butler [1991]; 2, Ekstrand and Butler [1989]; 3, Witte and Kent [1990]; 4, Witte et al. [1991]; 5, Larochelle and Currie [1967]; Robertson [1967]; 6, Hodych and Dunning [1992]; 7, this study; 8, Reeve [1975]; 9, Witte and Kent [1989]; and 10, Steiner [1986]. 


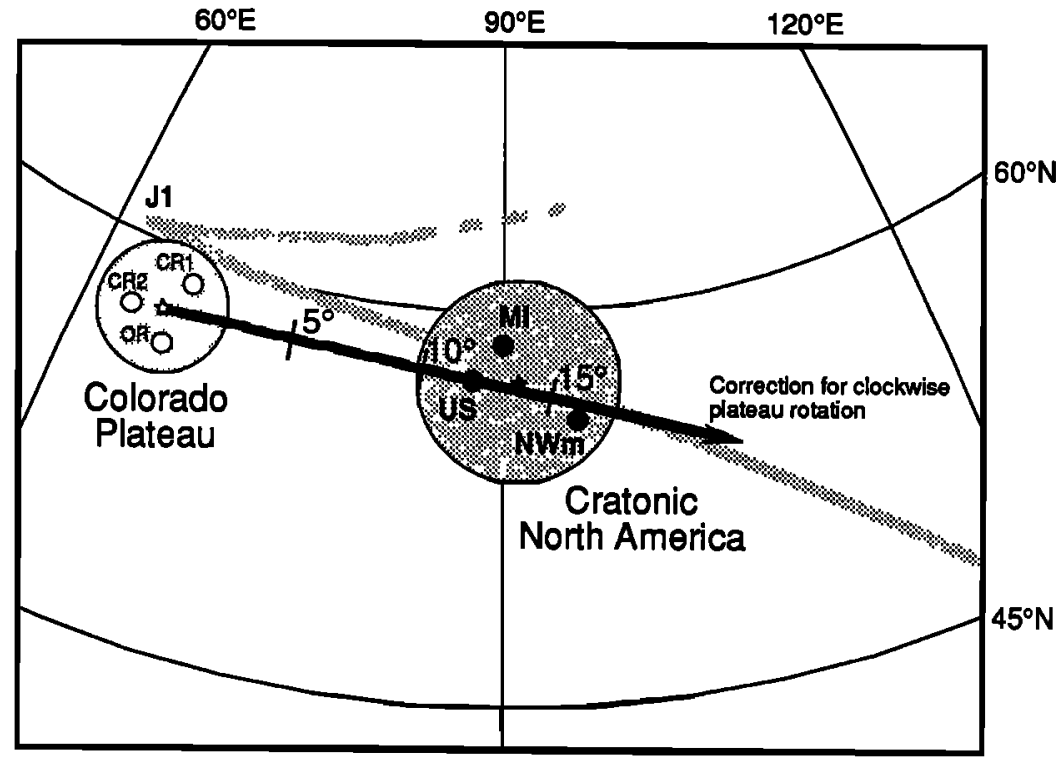

Fig. 2. Mean of Norian paleomagnetic poles for cratonic North America compared to mean of Norian poles for Colorado Plateau uncorrected for rotation, both with $95 \%$ confidence circles. Trajectory of mean plateau Norian pole with increasing amounts of correction for clockwise plateau rotation about Euler pole at $36^{\circ} \mathrm{N} 105^{\circ} \mathrm{W}$ is shown by arrow. Shown for reference by stippled curves are the Triassic paleomagnetic Euler pole (PEP) track, the Triassic/Jurassic or J1 cusp, and the ensuing portion of the Jurassic PEP track from Gordon et al. [1984].

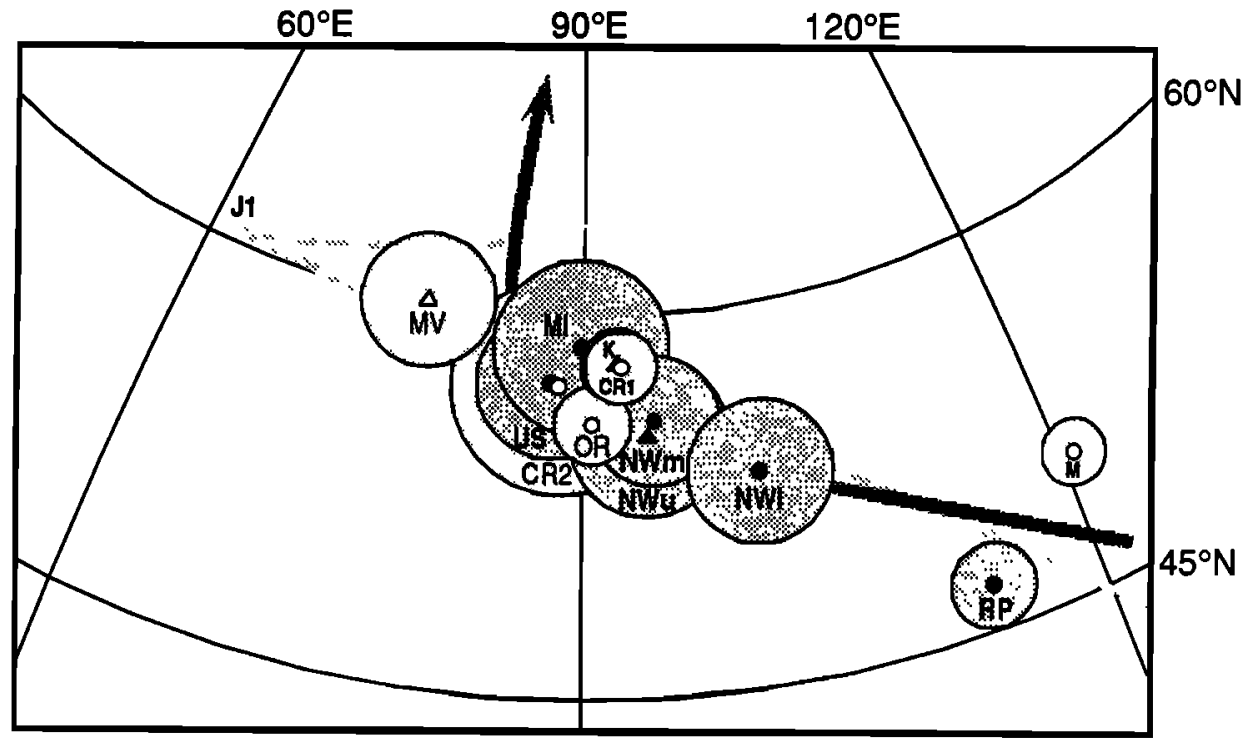

Fig. 3. Selected Triassic and Early Jurassic paleomagnetic poles for North America as in Figure 1 but with correction for $13.5^{\circ}$ clockwise rotation of the Colorado Plateau (Table 1). Shown for reference by light stippled curves are the Triassic paleomagnetic Euler pole (PEP) track, the Triassic/Jurassic or J1 cusp, and the ensuing portion of the Jurassic PEP track from Gordon et al. [1984]. Our interpretation of Triassic and Early Jurassic APW trajectory for North America is shown by the heavier stippled curve. 
Butler [1991] and in our present study of strata equivalent to the Church Rock member. The mean pole position for the three plateau Chinle poles at $57.7^{\circ} \mathrm{N} 65.6^{\circ} \mathrm{E}$ A95 $=2.5^{\circ}$, however, disagrees by over $13^{\circ}$ from the mean Norian paleopole for cratonic North America at $57.4^{\circ} \mathrm{N} 91.0^{\circ} \mathrm{E}$ A95 $=3.8^{\circ}$. The case for fast APW in the Late Triassic largely rests on the interpretation that most of this angular difference reflects an age progression within the Norian (e.g., between the pole from the early Norian Upper Shale member of the Chinle off the plateau and the pole from the middle Norian Owl Rock Member of the Chinle on the plateau corrected for only $4^{\circ}$ of plateau rotation [Bazard and Butler, 1991]). However, because the lower, middle, and upper Newark poles from rocks in stratigraphic succession show hardly any evolution in pole position across the Norian time interval, and the Norian middle Newark pole agrees with the Norian Upper Shale pole from off the Colorado Plateau, the difference is here interpreted to be predominantly a consequence of relative motion between the plateau and the craton since the Late Triassic.

\section{ESTIMATE OF COLORADO PLATEAU ROTATION}

To estimate the magnitude of Colorado Plateau rotation, we assume like Bryan and Gordon [1986, 1990] a model of APW for North America. Our model, however, features a virtual standstill in APW for the last $15 \mathrm{~m} . \mathrm{y}$. of the Late Triassic which allows us to directly compare the individual sets of reliable Norian poles from on and off the plateau. This approach thus resembles that of Steiner [1986, 1988] but in our case the potential problems of uncertainties in age correlation that can complicate the interpretation of pole-to-pole comparisons if APW was rapid are minimized.

An Euler pole located at $36^{\circ} \mathrm{N} 105^{\circ} \mathrm{W}$ was used to estimate the rotation of the Colorado Plateau with respect to cratonic North America since the Triassic. This Euler pole is a combination of Hamilton's [1981] Euler pole $\left(39^{\circ} \mathrm{N} 105^{\circ} \mathrm{W}\right)$ which describes clockwise rotation of the Colorado Plateau to account for structures associated with Cenozoic opening of the Rio Grande Rift, and Hamilton's [1988] revised Euler pole $\left(34^{\circ} \mathrm{N} 105^{\circ} \mathrm{W}\right)$ for clockwise plateau rotation to account for structures associated with the Laramide orogeny. Bryan and Gordon [1986, 1990] also approximated Hamilton's two-phase rotation of the Colorado Plateau by a single Euler pole, located in their case at $37^{\circ} \mathrm{N} 103^{\circ} \mathrm{W}$ using Hamilton's [1981] earlier estimate of the Euler pole $\left(35^{\circ} \mathrm{N} 101^{\circ} \mathrm{W}\right)$ for the Laramide phase. Steiner $[1986,1988]$ on the other hand attempted to constrain the location of the Euler pole from the same paleomagnetic data used to estimate the amount of plateau rotation.

Obtaining an estimate of Colorado Plateau rotation is straightforward. The mean plateau Norian pole $\left(57.7^{\circ} \mathrm{N} 65.6^{\circ} \mathrm{E}\right.$ $A 95=2.5^{\circ}$ ) is rotated about the Euler pivot until the angular

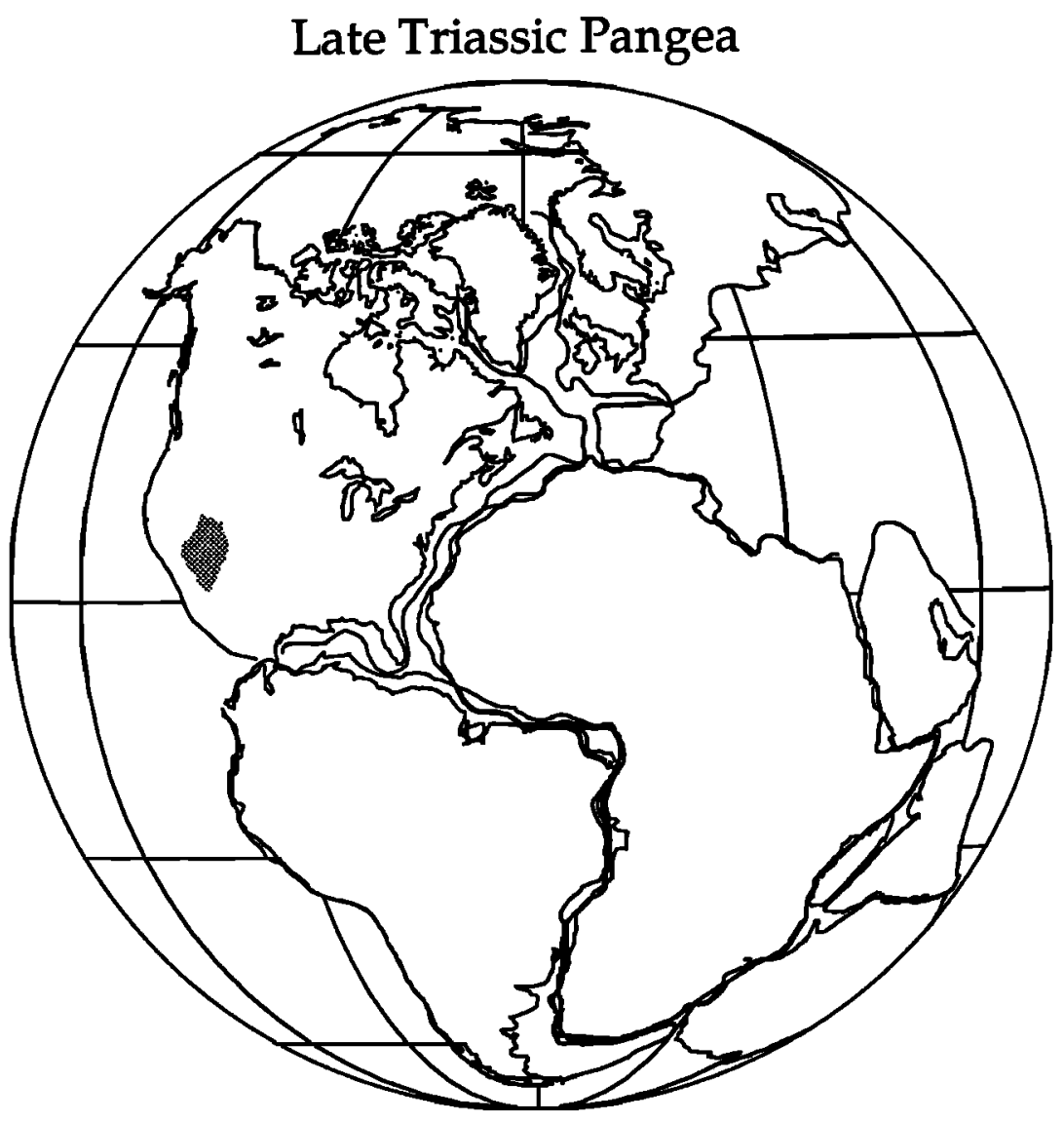

Fig. 4. Paleogeographic reconstruction for Pangea (after Ziegler et al. [1983] using Terra Mobilis ${ }^{\mathrm{TM}}$ ) positioned with respect to latitude according to mean Norian paleomagnetic pole $\left(57.4^{\circ} \mathrm{N} 91.0^{\circ} \mathrm{E} ;\right.$ Table 1$)$ for cratonic North America. Shaded area in North America is Colorado Plateau. 
difference with respect to the mean cratonic North American Norian pole $\left(57.4^{\circ} \mathrm{N} 91.0^{\circ} \mathrm{E} A 95=3.8^{\circ}\right)$ is minimized (Figure 2). A correction for $13.5^{\circ}$ of clockwise rotation reconciles the mean plateau Norian pole to within $1^{\circ}$ of the mean cratonic Norian pole. Confidence limits on the amount of rotation can be obtained using the statistics of McFadden and Lowes [1981]. We find that the plateau and cratonic North American mean poles for the Norian are not significantly different at the $95 \%$ confidence level at rotation angles from $10^{\circ}$ to $17^{\circ}$. Our analysis thus suggests that the Colorado Plateau rotated clockwise $13.5^{\circ} \pm 3.5^{\circ}$ with respect to cratonic North America since the Late Triassic. Alternative plateau-cratonic North America Euler poles yield practically the same clockwise rotations, for example, $13.6^{\circ}$ for the combined Euler pole used by Bryan and Gordon [1986, 1990], $13.7^{\circ}$ for just the Rio Grande Euler pole of Hamilton [1981], and $13.5^{\circ}$ for just the Laramide Euler pole of Hamilton [1988]. Thus, as observed by Bryan and Gordon [1990], estimates of the angle of rotation are insensitive to the precise choice of Euler pole, whose location is most usefully constrained by independent geologic criteria.

\section{CONSISTENCY WTTH OTHER PALEOMAGNETIC DATA}

The Early Triassic has been previously considered to provide the best set of interval paleopoles to document relative motion of the Colorado Plateau. Steiner [1986] determined that $11.7^{\circ} \pm 3.7^{\circ}$ of clockwise plateau rotation could be inferred from the discordance between the mean pole calculated from four published paleomagnetic studies of the Early Triassic Moenkopi Formation of the Colorado Plateau and the mean pole from three studies of the nominally coeval Red Peak Formation of Wyoming. Steiner [1986] (but see Bazard and Butler [1991]) argued that age uncertainties are unlikely to account for the discordance in pole positions from the Moenkopi and Red Peak rocks but cautioned that the cratonic coherence of the Red Peak sampling sites in Wyoming, an area affected by Laramide deformation, lacks confirmation.

Ambiguity related to the cratonic coherence of the deformed margins of the Colorado Plateau affects the interpretation of some other key paleomagnetic data sets. Data from the Early Permian Abo Formation have been regarded as providing a cratonic reference paleomagnetic pole because the formation crops out on the east side of the Rio Grande Rift [Gordon et al., 1984; Steiner, 1988; Bryan and Gordon, 1990]. Yet the recent study by Molina-Garza et al. [1991] shows that the Moenkopi Formation at their Sevilleta Grant sampling locality, on the eastern margin of the Rio Grande Rift just to the south of Steiner's [1988] study area of the Abo Formation at Abo Pass, gives a paleopole very similar to Moenkopi poles from two localities on the western (plateau) margin of the rift, which together resemble published Moenkopi poles from the interior of the Colorado Plateau. Moreover, at Tejon, a locality to the north of Abo Pass but also on the east side of the rift, magnetizations of the Shinarump member of the Chinle Formation were shown to contain Cretaceous(?) and recent overprints that were deflected clockwise by over $30^{\circ}$. Accordingly, Molina-Garza et al. [1991] suggested that portions of central New Mexico east of the rift may have either rotated rigidly with the plateau or experienced a similar sense of rotation by independent deformation mechanisms. In light of this evidence, the pole from the Shinarump member of the Chinle Formation [Molina-Garza et al., 1991] as well from the Early Permian Abo Formation [Steiner, 1988] should be considered suspect with regard to cratonic coherence. Plateaurelated rotation of the Abo Formation does, however, point to an alternative explanation for the long-recognized similarity of Permian poles from the plateau and the "craton" that has less to do with an additional Late Permian rotation of the plateau [Steiner, 1988] than with an inappropriate cratonic reference. Interestingly, Irving and Strong [1985] suggested the possibility of a large $\left(\sim 10^{\circ}\right)$ clockwise plateau rotation on the basis of an analysis of Kiaman (Permo-Carboniferous) overprint magnetizations in North American Paleozoic rocks.

\section{REVISED TRIASSIC/EARLY JURASSIC APW FOR NORTH AMERICA}

Paleomagnetic poles we use to delineate a Triassic to Early Jurassic APW path for North America generally conform to those discussed and deemed most reliable by Bazard and Butler [1991, Figure 14], with the addition of the recently published middle Newark pole [Witte et al., 1991] and our new Church Rock pole (Table 1). We did, however, choose to include the mean Red Peak and the mean Moenkopi poles as calculated by Steiner [1986] as reasonable if perhaps not precisely coeval (or in the case of the Red Peak, not strictly cratonic) Early Triassic counterparts from off and on the plateau. Paleomagnetic results of Reeve [1975] from the Church Rock member were also used on the strength of corroborating data from our study of equivalent stratigraphic units. To maintain consistency with Bazard and Butler [1991], we use their recalculation of the Church Rock pole that was based on only normal polarity data and note that Gordon et al. [1984] calculated a statistically indistinguishable pole $\left(61^{\circ} \mathrm{N} 64^{\circ} \mathrm{E} A 95=3^{\circ}\right)$ from Reeve's [1975] data for the Church Rock member that included normal and reversed polarities and passed a reversal test. Finally, we omit the Shinarump pole because of the complex tectonic setting with demonstrated local rotations where it was sampled [Molina-Garza et al., 1991].

Fig. A1. Paleomagnetic results from the Chinle Formation. (a) Map of sampling localities I (sites TCHF to TCHJ), II (sites TCHA to TCHE), III (sites TCHK to TCHM), and IV (sites TCHN and TCHO) in Utah. (b) Stratigraphic range of sampling sites shown by solid bars at the four localities (representative stratigraphic columns after Stewart et al., [1972]). (c-f) Demagnetograms for representative samples from the different localities. Open/solid symbols are vector end-points projected on vertical/horizontal orthogonal planes after each stage of thermal demagnetization. Samples in Figures Alc-Ale have reversed polarity, and sample in Figure Alf has normal polarity characteristic magnetization. (g) Site mean directions after tilt correction, with open/solid circles plotted on upper/lower hemisphere of equal area net. The two smaller circles are for sites TCHI and TCHJ from lower Chinle that were excluded in calculation of upper Chinle mean direction shown by star with corresponding circle of $95 \%$ confidence based on nine sites converted to common normal polarity (Table A1). 

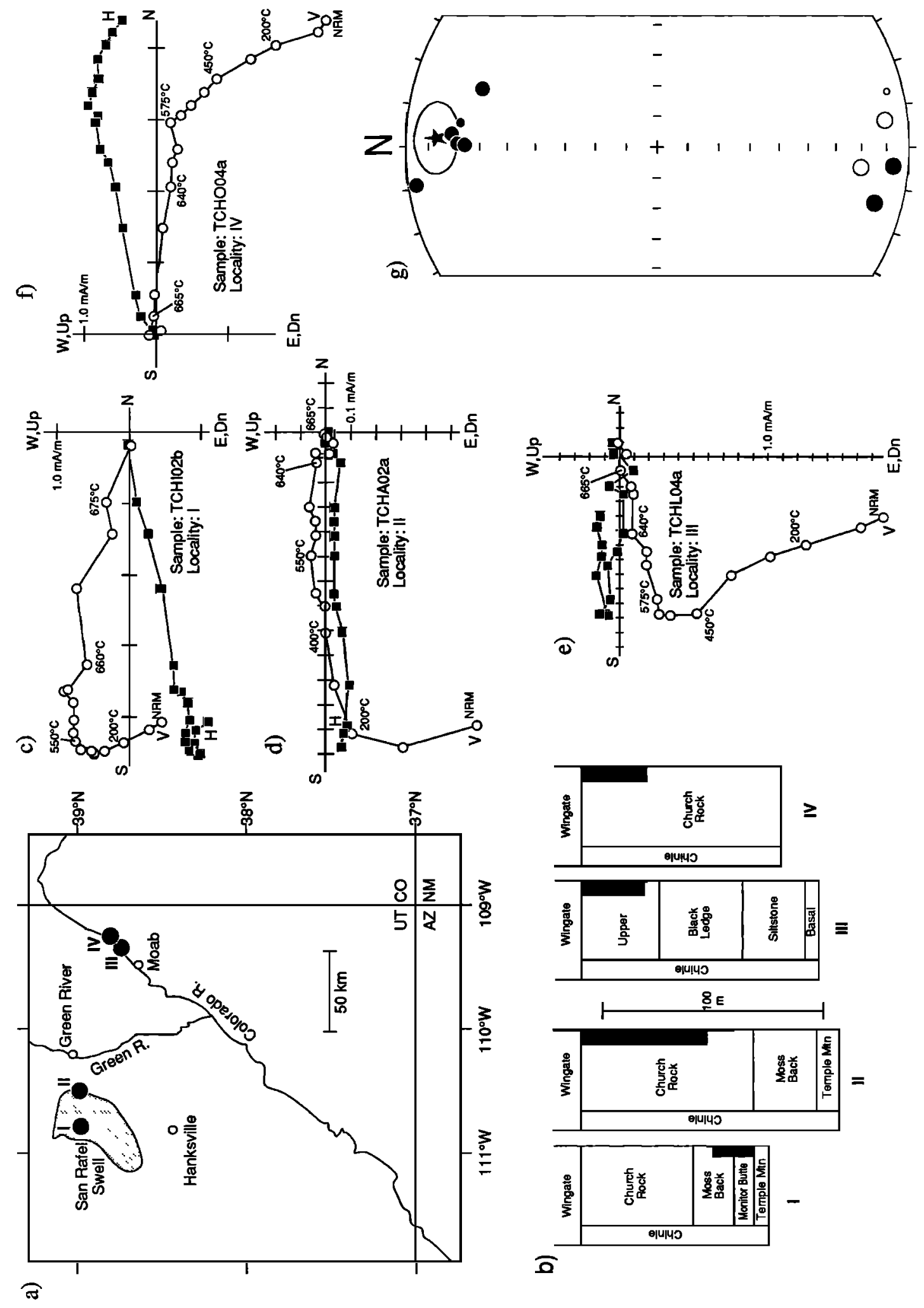
After $13.5^{\circ}$ correction for clockwise plateau rotation, the Triassic poles for North America describe an APW path from about $49^{\circ} \mathrm{N} 117^{\circ} \mathrm{E}$ in the Early Triassic to the virtual standstill at about $57^{\circ} \mathrm{N} 91^{\circ} \mathrm{E}$ by the Norian (Figure 3). APW over the Triassic was about $17^{\circ}$ of arc distance but the rate of angular change was not constant. Instead, an average rate of $0.73 \% \mathrm{~m}$.y. calculated for the entire Triassic by Bazard and Butler [1991] is more appropriate only for the Early and Middle Triassic because of negligible APW in the Norian. The Camian lower Newark pole may record an intermediate position of the Triassic APW shift (Figure 3).

The insignificant difference of the Hettangian upper Newark pole from the middle Newark and other Norian poles suggests that the standstill extended into the earliest Jurassic. However, the pole from the Sinemurian Moenave Formation [Ekstrand and Butler, 1989], even after $13.5^{\circ}$ correction for plateau rotation, falls significantly to the west of the upper Newark pole (Figure 3). The Moenave pole is based on thorough demagnetization experiments and although the mean normal and reversed directions are $12^{\circ}$ from antipodal, they formally pass a reversal test [class C [McFadden and McElhinny, 1990]). The Moenave may therefore record a westerly excursion in APW, an obtunded vestige of the J1 cusp of PEP models. If so, the Moenave excursion was rather brief because a new pole reported by Bazard and Butler [1991] from the immediately overlying (Pleinsbachian) Kayenta Formation after correction for $13.5^{\circ}$ of plateau rotation is hardly different from the Hettangian lower Newark pole. Furthermore, the Pleinsbachian Kayenta pole is not significantly different from Norian poles from the Owl Rock or Church Rock members of the Chinle Formation from the Colorado Plateau.

This apparent backtrack of the Kayenta pole was interpreted to mark the beginning of an easterly progression of paleopoles that define the J1 to J2 PEP Jurassic track [Bazard and Butler, 1991], but this interpretation will need to be reconciled with the emerging evidence for high latitude APW in the Jurassic [Van Fossen and Kent, 1990, 1992b; Witte and Kent, 1991]. To the extent that paleomagnetic poles from the Colorado Plateau are used, any revised Jurassic APW path for North America will also need to take into account a large clockwise plateau rotation. It can nevertheless be concluded at this stage that APW for North America must have been at a relatively rapid $(\sim 1 \%$ m.y.) overall rate in the Jurassic, to arrive at the distant and well-established mid-Cretaceous pole position at $71^{\circ} \mathrm{N}$ $196^{\circ} \mathrm{E}$ [Globerman and Irving, 1988].

\section{DISCUSSION}

Our paleomagnetic estimate of $13.5^{\circ}$ of clockwise plateau rotation based on Late Triassic data is similar to that of Steiner's [1986] $11.7^{\circ}$ based on Early Triassic data, but it is significantly greater $\left(13.5^{\circ} \pm 3.5^{\circ}\right.$ versus $\left.5.0^{\circ} \pm 2.5^{\circ}\right)$ than the value most recently calculated by Bryan and Gordon [1990] from late Paleozoic to Jurassic data. We suggest that Bryan and Gordon underestimated the amount of plateau rotation because they effectively averaged the large systematic discordance in Triassic poles with the generally small discordance of ambiguous significance in late Paleozoic poles, and used a Jurassic APW model that we now regard as poorly defined at best.

An undercorrection of plateau paleomagnetic poles for clockwise rotation ( $5^{\circ}$ or less) has contributed to the impression of fast APW continuing through the Late Triassic [Gordon et al., 1984; May and Butler, 1986; Bryan and Gordon, 1986, 1990; Bazard and Butler, 1991]. This is largely because the discondance between on-plateau and off-plateau Chinle poles was presumed to reflect mostly an age difference. Our interpretation predicts that the Late Triassic Chinle Formation should show little change in paleomagnetic pole position over its stratigraphic range at a given locality either on or off the plateau, corresponding to the lack of discernible APW we have documented for the broadly correlative Newark Basin section. For example, the Upper Petrified Forest member of the Chinle Formation on the Colorado Plateau (see Bazard and Butler [1991, Figure 15] for stratigraphic correlations) should give a pole position that is virtually the same as the available paleomagnetic poles for the Owl Rock and Church Rock members from the plateau, but that should differ from the reported pole for the presumably coeval Upper Shale member of east central New Mexico (off the plateau) by an amount that is equivalent within errors to $13.5^{\circ}$ of clockwise plateau rotation.

Hamilton [1988] estimated on geologic grounds that the Colorado Plateau rotated clockwise relative to the craton by about $8^{\circ}$ since mid-Cretaceous time: about $3^{\circ}$ was estimated to account for the regional pattem of extension associated with the Cenozoic opening of the Rio Grande Rift and the balance (in the range of $2^{\circ}$ to $8^{\circ}$ ) with a preceding Late Cretaceous phase of rotation to account for the spatial distribution of crustal shortening across the Laramide belt. Although Hamilton [1988] seemed to favor paleomagnetic estimates of plateau rotation that were relatively large [e.g., Steiner, 1986] compared to the $4^{\circ}$ estimated by Bryan and Gordon [1986], the compatibility of the geologic evidence for post-Triassic rotation of the Colorado Plateau that totals to the $\sim 13.5^{\circ}$ indicated by our analysis is not unequivocal [Chase et al., 1992] and will require further critical evaluation of the extent of Laramide shortening as well as Rio Grande Rift-related extension. Local clockwise rotations may also more broadly characterize the Cenozoic tectonic history of the westem interior of the United States [e.g., Eaton, 1979], as documented by paleomagnetic data from the eastern margin of the Rio Grande Rift [MolinaGarza et al., 1991] and suggested by systematic discrepancies with respect to global plate reconstructions of early Tertiary poles from westem United States sampling localities including north central Montana and northwestern Wyoming [Acton and Gordon, 1992].

Finally, the revised pattern of Triassic APW for North America can be viewed in a broader paleogeographic context. During the Triassic, North America was part of the supercontinent of Pangea. The virtual absence of APW for North America over $15 \mathrm{~m}$.y. of the Norian therefore implies that Pangea was also stationary with respect to the paleomagnetic reference frame during this time (Figure 4). The latitudinally static position of Pangea in the Late Triassic, preceded and followed by time intervals characterized by fast APW of up to $\sim 1 \%$ m.y., may be related to large-scale mantle processes [Gumis, 1988]. In practical terms, the Norian standstill of APW is an ideal time interval for testing and refining models of Pangea continental reconstructions as well as for terrane (e.g., Colorado Plateau) analysis.

\section{APPENDIX: NEW CHINLE PALEOMAGETIC RESULTS}

At least five oriented drill core samples were taken from each of a total of 15 sites distributed over two localities along Interstate 70 on the the San Rafael Swell in western Utah, and two localities along the Colorado River near Moab in eastern 
TABLE A1. Characteristic Magnetization Directions From the Chinle Formation

\begin{tabular}{|c|c|c|c|c|c|}
\hline Site & $\mathrm{n} / \mathrm{N}$ & $\mathbf{k}$ & $\begin{array}{c}\text { Dec, } \\
\text { degrees }\end{array}$ & $\begin{array}{l}\text { Inc, } \\
\text { degrees }\end{array}$ & Stk/Dip \\
\hline TCHA & $3 / 5$ & 231 & 185.6 & -19.6 & $008 / 30 \mathrm{E}$ \\
\hline TCHB & $4 / 4$ & 37 & 2.0 & 21.5 & $013 / 25 E$ \\
\hline TCHD & $5 / 5$ & 8 & 4.1 & 19.5 & $018 / 28 E$ \\
\hline TCHE & $6 / 6$ & 12 & 18.7 & 27.8 & $008 / 28 \mathrm{E}$ \\
\hline TCHI* & $4 / 5$ & 79 & 166.2 & -7.2 & $000 / 00 \mathrm{E}$ \\
\hline TCHJ* & $6 / 7$ & 35 & 7.2 & 22.1 & 000/00E \\
\hline TCHK & $5 / 8$ & 12 & 194.2 & 11.7 & $113 / 10 S$ \\
\hline TCHL & $5 / 5$ & 36 & 184.3 & 6.5 & $113 / 10 S$ \\
\hline TCHM & $5 / 8$ & 49 & 173.0 & -9.9 & $113 / 10 S$ \\
\hline TCHN & $6 / 6$ & 25 & 1.0 & 24.8 & $000 / 00 S$ \\
\hline TCHO & $5 / 6$ & 182 & 351.0 & 3.7 & $000 / 00 \mathrm{~S}$ \\
\hline Mean & $9 / 15$ & 24 & 003.6 & 12.3 & $\left(\mathrm{a} 95=10.7^{\circ}\right)$ \\
\hline \multicolumn{2}{|c|}{ Pole position: } & \multicolumn{4}{|c|}{$\begin{array}{c}\text { Lat }=57.5^{\circ} \mathrm{N} \quad \text { Lon }=63.3^{\circ} \mathrm{E} \\
\left(\mathrm{K}=50, \mathrm{~A} 95^{\circ}=7.3^{\circ}\right)\end{array}$} \\
\hline
\end{tabular}

Column heads are $n / N$, number of samples or sites used for calculation/number collected; $\mathbf{k}$, estimate of Fisher precision parameter; Dec, declination and Inc, inclination of magnetization direction after bedding tilt correction; Stk/Dip, bedding strike/bedding dip with quadrant direction. Lat is latitude and Lon is longitude of paleomagnetic pole position based on nine site mean virtual geomagnetic poles; $K$ is estimate of Fisher precision parameter; and A95 is radius of cone of $95 \%$ confidence about pole.

*These sites were excluded (see text).

Utah (Figure Ala). The Chinle Formation in this region is a shallow lacustrine and fluvial unit with considerable lateral variability and correspondingly varied stratigraphic nomenclature [Stewart et al., 1972]. Our sampling concentrated on the upper portions of the formation, with 10 sites in the
Church Rock member or its stratigraphic equivalent at localities II, III, and IV, but the five sites at locality I were taken in the Monitor Butte and Moss Back members (Figure Alb). All experimental work was conducted in a magnetically shielded room using procedures and equipment described by Witte et al. [1991]. Sample magnetization directions were determined by principal component analysis [Kirschvink, 1980] and averaged using Fisher [1953] statistics. Although some medium grain size sandstones were sampled, red mudstone samples yielded the most interpretable demagnetization results.

Complete stepwise thermal demagnetization to $680^{\circ} \mathrm{C}$ of all samples typically revealed two components of magnetization, similar to demagnetization behaviour described by Bazard and Butler [1991] for the Owl Rock member. There is often a northerly and steeply down magnetization, with unblocking temperatures to about $500^{\circ} \mathrm{C}$, that most likely represents a recent overprint (Figure Alc). Eleven sites of the original 15 produced at least three samples with a well-defined high unblocking temperature component, evidently carried by hematite, with either shallow and northerly or shallow and southerly directions (Figure A1d). The 11 sites have a mean direction after tilt correction of Declination/Inclination = $2.3^{\circ} / 12.8^{\circ}, \mathrm{k}=26, \mathrm{a95}=9.2^{\circ}$. Excluding two of these 11 sites which are from the lower part of the Chinle (Monitor Butte and Moss Back members), we calculate a mean direction for the upper part of the Chinle at Declination/Inclination $=3.6^{\circ} / 12.3^{\circ}$, $k=24, a 95=10.7^{\circ}$ (Table A1) and note that the five normal polarity and four reversed polarity site means pass a reversal test (class C [McFadden and McElhinny, 1990]). The pole position based on these nine sites $\left(57.5^{\circ} \mathrm{N} 63.3^{\circ} \mathrm{E} A 95=7.3^{\circ}\right)$ is not significantly different from the pole $\left(59.0^{\circ} \mathrm{N} 67.0^{\circ} \mathrm{E} A 95=2.5^{\circ}\right)$ calculated by Bazard and Butler [1991] from Reeve's [1975] data for the Church Rock member.

Acknowledgments. We thank the journal reviewers for constructive comments. This research was supported by the National Science Foundation, Division of Earth Sciences (grants EAR87-21142 and EAR89-16726) and is LamontDoherty Geological Observatory contribution 4996.

\section{REFERENCES}

Acton, G.D., and R.G. Gordon, Paleomagnetic tests of plate motion circuits over the past 73 million years with implications for circum-Pacific plate motions and motions between hotspots (abstract), Eos Trans, AGU, 73(14), Spring Meeting Suppl., 52, 1992.

Bazard, D.R., and R.F. Buller, Paleomagnetism of the Chinle and Kayenta formations, New Mexico and Arizona, J. Geophys. Res., 96, 9847-9871, 1991.

Bryan, P., and R.G. Gordon, Rotation of the Colorado Plateau: An analysis of paleomagnetic data, Tectonics, 5, 661-667, 1986.

Bryan, P., and R.G. Gordon, Rotation of the Colorado Plateau: An updated analysis of paleomagnetic poles, Geophys. Res. Lett., 17, 1501-1504, 1990.

Butler, R.F., S.R. May, and D.R Bazard, Comment on "High-Latitude Paleomagnetic Poles From Middle Jurassic Plutons and Moat Volcanics in
New England and the Controversy Regarding Jurassic Apparent Polar Wander for North America" by M.C. Van Fossen and D.V. Kent, J. Geophys. Res., 97, 1801-1802, 1992.

Chase, C.G., K.M. Gregory, and R.F. Butler, Geologic constraints on amounts of Colorado Plateau rolation (abstract), Meeting, Eos Trans. AGU, 73(14) Spring Meeting Suppl., 95, 1992.

Comer, B., and P.E. Olsen, A summary of the biostratigraphy of the Newark Supergroup of eastem North America with comments on Early Mesozoic provinciality, in III Congresso Latinoamericano de Paleontologia, Mexico. Simposio Sobre Floras del Triasico Tardio, su Filogeografia y Paleoecologia, Memoria, Pp. 67.81, 1985.

Dunning, G.R., and J.P. Hodych, U/Pb zircon and baddeleyite ages for the Palisades and Gettysburg sills of the northeastem United States: Implications for the age of the
Triassic/Jurassic boundary, Geology, 18, 795 798, 1990.

Eaton, G.P., A plate-tectonic model for late Cenozoic crustal spreading in the westem United States, in Rio Grande Rift: Tectonics and Magmatism, edited by R.E. Riecker, pp. 7-32, AGU, Washington, D. C., 1979.

Ekstrand, E.J., and R.F. Butler, Paleomagnetism of the Moenave Formation: Implications for the Mesozoic North American apparent polar wander path, Geology, 17, 245-248, 1989.

Fisher, R.A., 1953, Dispersion on a sphere, Proc. R. Soc. London Ser A, 217, 295-305, 1953.

Globerman, B.R., and E. Irving, Mid-Cretaceous paleomagnetic reference field for North America: Restudy of $100 \mathrm{Ma}$ intrusive rocks from Arkansas, J. Geophys. Res., 93, 11,72111,733, 1988.

Gordon, R.G., A. Cox, and S. O'Hare, Palcomagnetic Euler poles and the apparent 
polar wander and absolute motion of North America since the Carbonifenous, Tectonics, 3, 499-537, 1984.

Gumis, M., Large-scale mantle convection and the aggregation and dispersal of supercontinents, Natwe, 332, 695-699, 1988.

Hamilion, W., Plate-tectonic mechanism of Laramide deformation, Contrib. Geol., 19, 8792., 1981.

Hamilton, W., Tectonic seuings and variations with depth of some Cretaceous and Cenozoic structural and magmatic aystems of the westem United States, in Metamorphism and Crustal Evolution of the Western United States, Rubey Volune VII, edited by W.G. Emst, pp. 1-40, Prentice-Hall, Englewood Cliffs, N.J., 1988.

Harland, W.B., R.L. Amstrong, A.V. Cox, L.E. Craig, A.G. Smith, and D.G. Smith, A Geologic Time Scale 1989, Cambridge University Press, New York, 1990.

Hodych, J.P., and G.R. Dunning, Did the Manicouagan trigger end-of-Triassic mass extinction?, Geology, 20, 51-54, 1992.

Irving, E., and D.V. Strong, Paleomagnetism of rocks from Burin Peninsula, Newfoundland: Hypothesis of Late Devonian displacement of Acadia criticized, J. Geophys. Res., 90, 1949$1962,1985$.

Kent, D.V., P.E. Olsen, and W.K.Wilte, Late Triassic magnetostratigraphy from the Newark Rift Basin Coring Project: Initial results (abstract), Eos Trans. AGU, 72(17), Spring Meeting Suppl., 101, 1991.

Kirschvink, J.L., The least-squares line and plane and the analysis of paleomagnetic data, Geophys. J. R. Astron. Soc., 62, 699-718, 1980.

Kodama, K.P., Comment on "Paleomagnetism of Early Jurassic rocks, Watchung Mountains, Newark Basin: Evidence for complex rotations along the border fault", Geophys. Res. Lett., 14, 239-241, 1987.

Larochelle, A., and K.L. Currie, Paleomagnetic study of igneous rocks from the Manicouagan Structure, Quebec, J. Geophys. Res., 72, 4163 $4169,1967$.

May, S.R., and R.F.Butler, North American Jurassic apparent polar wander: Implications for plate motion, paleogeography, and Cordilleran tectonics, J. Geophys. Res., 91, 11,519-11,544, 1986.

McFadden, P.L., and F.J. Lowes, The discrimination of mean directions drawn from Fisher distributions, Geophys. J. R. Astron. Soc., 67, 19-33, 1981.

McFadden, P.L., and M.W. McElhinny, Classification of the reversal test in paleomagnetism, Geophys. J. Int., 103, 725729, 1990.
McIntosh, W.C., R.B. Hargraves, and C.L. West, Paleomagnetism and oxide mineralogy of Upper Triassic to Lower Jurassic red beds and basalts in the Newark basin, Geol. Soc. Am. Bull., 96, 463- 480, 1985.

Molina-Garza, R.S., J.W. Geissman, R. Van der Voo, S.G. Lucas, and S.N. Hayden Paleomagnetism of the Moenkopi and Chinle Formations in Central New Mexico: Implications for the North American Apparent Polar Wander Path and Triassic Magnetostratigraphy, $J$. Geophys. Res., 96, 14,239-14,262, 1991.

Olsen, P.E., and M. Fedosh, Duration of the early Mesozoic extrusive igneous episode in eastem North America determined by use of Milankovitch-type cycles, Geol. Soc. Am. Abstr. Programs, 20, 59, 1988.

Olsen, P.E., and H.D. Sues, Correlation of continental Late Triassic and Early Jurassic sediments and pattems of the Triassic-Jurassic tetrapod transition, in The Beginning of the Age of Dinosaurs: Faunal Change Across the Triassic-Jurassic Boundary, edited by $K$. Padian, pp. 321-351, Cambridge University Press, New York, 1986.

Ratcliffe, N.M., W.C. Burton, R.M. D'Angelo, and J.K. Costain, Low-angle extensional faulting, reactivated mylonites, and seismic reflection geometry of the Newark basin margin in eastem Pennsylvania, Geology, 14, 766-770, 1986.

Reeve, S.C., Paleomagnelic studies of sedimentary rocks of Cambrian and Triassic age, Ph.D. thesis, 426 pp., Univ. of Tex., Dallas, 1975.

Robertson, W.A., Manicouagan, Quebec paleomagnetic results, Can. J. Earth Sci., 4. 641-649, 1967.

Smith, T.E., and H.C. Noluimier, Paleomagnetism of the Newark trend igneous rocks of the north central Appalachians and the opening of the central Atlantic Ocean, Am. J. Sci., 279, 778 807, 1979.

Steiner, M.B., Rotation of the Colorado Plateau, Tectonics, 5, 649-660, 1986.

Steiner, M.B., Paleomagnetism of the late Pennsylvanian and Pemian: $A$ test of the rotation of the Colorado Plateau, J. Geophys. Res., 93, 2201-2215, 1988.

Stewart, J.H., F.G. Poole, and R.F. Wilson, Stratigraphy and origin of the Chinle Formation and related Upper Triassic strata in the Colorado Plateau region, U.S. Geol. Surv. Prof Pap., 690, 1972.

Sutter, J.F., Innovative approaches to the dating of igneous events in the early Mesozoic basins of the eastem United States, in Studies of the Early Mesozoic Basins of the Eastem United States. edited by A.J. Froelich and G.R. Robinson, U.S Geol. Surv. Bull., I776, 194-200, 1988.
Swanson, M.T., Preexisting fault control for Mesozoic basin formation in eastem North America, Geology, 14, 419-422, 1986.

Van Fossen, M.C., and D.V. Kent, High latitude paleomagnetic poles from Jurassic plutons and moat volcanics in New England and the controversy regarding Jurassic apparent polar wander for North America, J. Geophys. Res., 95, 17,503-17,516, 1990.

Van Fossen, M.C., and D.V. Kent, Reply to R.F. Buler, S.R. May, and D.R. Bazard, J. Geophys. Res., 97, 1803-1805, 1992 a.

Van Fossen, M.C., and D.V. Kent, Paleomagnetism of the Front Range Morisson Formation and an altemative model of late Jurassic apparent polar wander for North America, Geology, 20, 223. 226, $1992 \mathrm{~b}$.

Van Fossen, M.C., JJ. Flynn, and R.D. Forsythe, Paleomagnetism of Early Jurassic rocks, Watchung Mountains, Newark Basin: Evidence for complex rotations along the Border fault, Geophys. Res. Lett., 13, 185-188, 1987.

Van Fossen, M.C., J.J. Flynn, and R.D. Forsythe, Reply to K.M. Kodama, Geophys. Res. Letl., 14, 242-244, 1987.

Webb, J.A., A radiometric time scale of the Triassic, J. Geol. Soc. Aust., 28, 107-121, 1981.

Witte, W.K., and D.V. Kent, A middle Camian to early Norian (-225 Ma) paleopole from sediments of the Newark basin, Pennsylvania, Geol. Soc. Am. Bull., 101, 1118 - 1126, 1989.

Witte, W.K., and D.V. Kent, The paleomagnetism of red beds and basalts of the Hettangian Extrusive Zone, Newark Basin, New Jersey, J. Geophys. Res., 95, 17,533-17,545, 1990.

Witte, W.K., and D.V. Kent, Tectonic implications of a remagnetization event in the Newark Basin, J. Geophys. Res., 96, 19,569-19,582, 1991.

Witte, W.K., D.V., Kent, and P.E. Olsen, Magnetostratigraphy and paleomagnetic poles from the Late Triassic-earliest Jurassic strata of the Newark basin, Geol. Soc. Am. Bull., 103, 1648-1662, 1991.

Ziegler, A.M., C.R. Scotese, and S.F. Barrett, Mesozoic and Cenozoic paleogeographic maps, in Tidal Friction and the Earth's Rotation II, edited by P. Borsche and J. Sundermann, pp. 240-252, Springer-Verlag, New York, 1983.

D. V. Kent and W. K. Witte, Lamont-Doherty Geological Observatory of Columbia University, Palisades, NY 10964.

(Received February 18, 1992

revised August 10, 1992;

accepted August 18, 1992.) 